\title{
FUTURE SPECIALIST PROFESSIONAL COMPETENCE DEVELOPING BY TEACHING PROFESSIONALLY - ORIENTED FOREIGN LANGUAGE TO NON-LINGUISTIC UNIVERSITY STUDENTS
}

The article deals with new approaches to teaching foreign languages in the professional direction at higher non-linguistic educational institutions. Professionally-oriented foreign language teaching is now recognized as the priority in renewal of the Ukrainian higher education.

Foreign language communication becomes an essential component of a specialist's future professional activity, and therefore the role of the discipline "Foreign Language" at non-linguistic faculties and technical educational institutions increases significantly. This fact encourages teachers and scientists to search for new approaches to teaching professionally-oriented foreign languages.

The issue of improving the effectiveness of foreign language training has always been the focus of attention of foreign language teachers. It is particularly acute for non-linguistic universities. Foreign language teachers at Ukrainian technical universities face many problems. They need to be solved, searched for and implemented at educational activities that would help optimize teaching.

The rapid development of information technologies, the globalization of the international labour market, growing competition and commercialization exacerbate the contradictions between new high requirements to knowledge, skills and abilities of future specialists and their insufficient level of foreign language proficiency.

Our article highlights the issue of changing the approach to teaching foreign languages, because with minimum educational hours in the curriculum you need to prepare a specialist who can use foreign language for job-related purposes. It may become possible through the formation of student's necessary communicative ability in the professional communication areas in oral and written form, that is, the development of communication skills. Communicative and professional competences provide a student with the opportunity to act using specific linguistic means in future employment field. Therefore, teachers of foreign languages are looking for new approaches to enhance the educational activities of students.

Key words: communicative and professional competences, non-linguistic university students, foreign language training, methods and approaches.

Problem statement. In the modern world, with the expansion of international relations in the political, socio-economic, educational and cultural spheres of society, the role of a foreign language in the process of integration of Ukrainian educational and scientific organizations into the world community is significantly increasing.

Currently, knowledge of a foreign language is mandatory for a specialist of any profile. A modern specialist should be ready to establish cross-cultural scientific relations, participate in international conferences, study foreign experience in a particular industry, and make business and partnership contacts. In this regard, at the present stage of development of science, education and technology, the problem of teaching a foreign language in non-linguistic universities is particularly relevant, since changes in the nature of education are increasingly focusing on creative initiative, student independence, competitiveness and mobility of future specialists.

Analysis of recent publications indicates that there is a significant number of scientific research in such directions: innovative approaches to teaching foreign languages in training specialists (T. Vakolyuk, O. Plotnikova, L. Chernovatyi, T. Varianko, L. Ivanchenko); organization of students' work during foreign language practical classes (O. Tarnopolsky, O. Kulkina, N. Gez, V. Lapidus, M. Lyakhovitsky etc.).

Purpose of the article. The main purpose of this article is to outline the main features and advantages of new methods and approaches to teaching professionally-oriented foreign language at non-linguistic educational institutions that exist in Ukraine; to make suggestions for their use at practical classes that involve consideration of the following interrelated factors: basic language knowledge, communication skills, knowledge of relevant disciplines, speciality terminology.

Presentation of the main material. According to the documents on modernization of higher professional education, foreign language proficiency should be an integral part of professional training at the University; the study of a foreign language should be based on an interdisciplinary integrative basis; training should be aimed at the development of multicomponent general cultural and professional competencies of students [9].

Since a foreign language is an effective means of acquiring professional skills and contributes to the professional growth of a future specialist, its study should be conducted in accordance with students' future specialty. Therefore, we may conclude that the content of foreign language teaching depends on University and faculty specifics. Such teaching at technical Universities can be successful if the so-called oriented selection of text material is consistently carried out during the entire training process, taking into account students' professional orientation and speciality. This activates students' communicative and cognitive activity, awakens interest in the subject and stimulates students to independent search for new words, expressions, specific terms and the use of different information sources. 
In accordance with the discipline standard, foreign language training should be communicatively- and professionally- oriented. The main goal of teaching foreign languages is formation, improvement and development of a specialist capable of achieving the necessary level of communicative and professional competences. The training is also aimed at developing cognitive independence of future specialists based on the formation of linguistic and professional orientations in the process of working with foreign literature and other sources of information in the chosen specialty.

Nowadays we see that PCs and information technologies have significantly simplified and diversified the ways of foreign language learning, while making the process much more entertaining and interesting. In addition, widespread computerization and rapid development of technologies have significantly facilitated the work of the teacher at higher educational establishments.

Outdated methods are simply not suitable for the modern generation of students, and the use of Information and Communication Technology (ICT) methods provides a unique opportunity for both teachers and students to go beyond the standard techniques, and contributes to effective self-monitoring. Technology can be motivating and offer the possibility to work autonomously or interact and collaborate with others. Technology also provides instant feedback on language performance in various tasks and exercises. Technology can also be an extension of classroom classes and can be time saving. Finally, technology can promote language learning with fresh authentic and motivating materials used from the Internet [10].

Nevertheless, teachers of higher educational institutions should not forget to combine the principles of professionally oriented training and the differentiated individual approach. It is also important to choose the most appropriate ones based on the context of the information being studied. However, there is no single best way because the level of foreign language knowledge is different.

One of the most effective methods that can be used at professional foreign language training is the case-study. It means the analysis of a specific situation [11].

In other words, learning English occurs by analysing certain situational professional tasks. We use it for analysing specified professionally-oriented tasks.

The main goal of the method is to develop students' analytical abilities and ability to understand the essence of problems, to teach them to find some ways to solve them and choose the best among them.

Cases are divided into:

- Practical that represent situations that occur in real life;

- Educational that are created artificially and are a conditional reflection of real life circumstances;

- Research that are created for investigating circumstances using situation modelling [11].

The case study method forms and improves a number of important skills:

- analytical skills for analysing the data provided, classifying them, dividing them into priority and less important, logical thinking skills;

- practical skills develop students' ability to apply in practice various ways to solve the task and achieve the goal;

- creative skills reveal the potential of non-standard thinking;

- communication skills are used for conducting debates and defending one's own position, as well as for correctly using data to compile a summary;

- social-interaction skills are necessary at teamwork: the ability to conduct a dialogue, to listen and to respond to the opponent [7].

To be used in professionally oriented teaching the case must meet the following requirements:

- have a clearly defined professional task;

- the complexity of the situation and task must match the level of the students group;

- contain multiple accents;

- the situation must be relevant and correspond to the real situation in the modern world of specific professional field;

- encourage analysis of the professional situation in general and specific data in particular;

- the situation must be provocative in order to encourage debate within the group of students;

- assume the variability of solutions and possible results [11].

Another modern method that we can suggest for using at professionally oriented foreign language training modern students is Content and Language Integrated Learning (CLIL), which is interesting and relevant. D. Marsh introduced the term in 1994 to refer to the totality of the methods of learning content (any subject) through a foreign or second language. CLIL refers to situations where the entire subject or a part of it is laid out through a foreign language with a dual purpose - the simultaneous learning of the subject itself and a foreign language [8].

D. Coyle formulates the fundamental principles of subject-language integrated learning (4 "Cs" of CLIL):

1) Content-content (getting and understanding new knowledge and skills). This principle puts the study of the content of a particular subject and the acquisition of knowledge and skills in this subject at the centre of the educational process;

2) Communication - communication (interaction, the process of learning the language itself and the use of language to acquire knowledge). The second principle defines language as a channel for communication and learning. 
The language is learned by using it in authentic, "untrained" situations. This fact is necessary for improving communicative and professional competences;

3) Cognition-cognition (cognition, participation in the process of thinking and understanding, solving problem situations). The third principle means that CLIL should activate cognitive abilities of students in connection with the development of basic interpersonal communication skills and educational and cognitive language competencies;

4) Culture - Citizenship - Culture (the path to intercultural understanding and the growth of civic consciousness) [4].

CLIL is recognized by the European Commission as very important, as it can provide students with the opportunity to apply new language skills in the present instead of learning the language now and applying it later. In addition, language learning does not require additional hours in the curriculum, which is of particular interest to professional educational institutions [3].

Foreign researchers in the field of teaching foreign language for specific purposes (LSP) emphasize the importance of active development of the following aspects for specialist professional growth in the conditions of globalization: speaking and listening to presentations, taking part at conferences and communication with colleagues and clients by phone; and reading and writing - for writing and studying e-mails, reports, memos, etc. [5].

However, because the number of hours spent in the classroom has declined sharply and distance education due to the pandemic was introduced these issues are not given enough attention.

Conclusions and suggestions. Summing up the above, we can state, that rapid changes in the modern world and globalization require foreign language teachers of higher educational establishments to improve teaching methods and approaches, to update their own knowledge, and to use innovative tools in their activities as a foreign language plays an important role in specialist training. The ability to carry out professionally-oriented foreign language communication is a relevant factor in students' professional and career growth. Along with other disciplines, a foreign language participates in the formation of professionally important qualities of a specialist. These qualities may have common and specific features, and it is important to take into account both in teaching professionally-oriented foreign-language communication to non-linguistic university students.

The problem of professionally oriented foreign language training is one of the most difficult and remains opened for the further methodical researching and improving.

Bibliography:

1. Абрамович Г. Суть іншомовної компетентності як мети та результату професійної технічної освіти. Наукові записки. Серія “Психолого-педагогічні науки”. Ніжин : Видавництво НДУ ім. Миколи Гоголя, 2005. № 4. С. 120-122.

2. Варянко Т. Навчання читання науково-технічних текстів у немовних вищих навчальних закладах. Сучасні методи викладання іноземної мови професійного спрямування у вищій школі : матеріали V Міжнародної науково-практичної конференції, 5-25 квітня 2012 р. Національний технічний університет України “Київський політехнічний інститут”, 2012. C. $15-17$.

3. Програма з англійської мови для професійного спілкування / колектив авторів : Г. Бакаєва та ін. Київ : Ленвіт, 2005. 119 с.

4. Collis B., Moonen Jef. Flexible Learning in a Digital World : Experiences and Expectations. London, 2001. 232 p.

5. Commission of the European Communities. Promoting Language Learning and Linguistic Diversity: An Action Plan 2004-2006. URL: http://ec.europa.eu/languages/eu-language-policy/action-plan-orlanguages_en.htm (дата звернення: 26.09.2020).

6. Coyle D. CLIL Content and Language Integrated. CUP, 2010.

7. Frendo E. How to Teach Business English. Pearson Longman, 2008. 162 p.

8. Hutchinson T., Waters A. English for specific purposes: a learning-centered approach. Cambridge : Cambridge University Press, 1987.

9. Mackay Ronald, Mountford Alan (Eds.). English for Specific Purposes : A Case Study Approach. London : Longman, 1978.

10. Marsh D. Content and Language Integrated Learning: The European Dimension - Actions, Trends and Foresight Potential. OUP, 2002. $204 \mathrm{p}$.

11. Rhalmi M. ICT Tools and English Language Teaching. URL: https://www.myenglishpages.com/blog/ict-tools-and-englishlanguage-teaching/ (дата звернення: 20.10.2020).

12. Spence, P. Engineering English and the hightech industry: A case study of an English needs analysis of process integration engineers at a semiconductor manufacturing company. Elsevier, 2013. Vol. 32. Issue 2. P. 97-109. URL: http://www.sciencedirect.com/ science/article/pii/S088949061200066X (дата звернення: 25.09.2020).

13. Varianko V., Ivanchenko L. M. Professionally-oriented foreign language teaching at higher technical educational institutions. Гуманітарний вісник ДВНЗ "Переяслав-Хмельнииький державний педагогічний університет імені Григорія Сковороди”. Додаток 3 до Вип. 36. Т. II (18) : Тематичний випуск “Міжнародні Челпанівські психолого-педагогічні читання". Київ : Гнозис, 2016. С. 261-268. URL: http://chelpanov.eeipsy.org/index.php/eeip/issue/view/9/PDF18 (дата звернення: 25.08.2020).

\section{References:}

1. Abramovych H. V. (2005) Sut inshomovnoi kompetentnosti yak mety ta rezultatu profesiinoi tekhnichnoi osvity [The essence of foreign language competence as a goal and result of professional technical education]. Naukovi zapysky. Seriia: Psykholohopedahohichni nauky. Nizhyn: Vydavnytstvo NDU im. Hoholia. № 4, 120-122. [in Ukrainian].

2. Collis B., Jef Moonen. (2001) Flexible Learning in a Digital World: Experiences and Expectations: London.

3. Commission of the European Communities (2003). Promoting Language Learning and Linguistic Diversity: An Action Plan 2004-2006. URL: http://ec.europa.eu/languages/eu-language-policy/action-plan-orlanguages_en.htm. (data zvernennia: 26.09.2020).

4. Coyle, D. (2010) CLIL Content and Language Integrated Learning CUP. 
5. Frendo E. (2008) How to Teach Business English Pearson Longman.

6. Hutchinson, T., Waters, A. (1987) English for specific purposes: a learning-centered approach, Cambridge University Press. Cambridge.

7. Mackay, Ronald and Alan Mountford (Eds.) (1978). English for Specific Purposes: A Case Study Approach. London: Longman.

8. Marsh, D. (2002) Content and Language Integrated Learning: The European Dimension - Actions, Trends and Foresight Potential. OUP

9. Prohrama $\mathrm{z}$ anhliiskoi movy dlia profesiinoho spilkuvannia (2005). [English language program for professional communication] Kolektyv avtoriv: H. Ye. Bakaieva, O. A. Borysenko, I. I. Zuienok ta in. K.: Lenvit. [in Ukrainian].

10. Rhalmi M. (2017) ICT Tools and English Language Teaching. URL: https://www.myenglishpages.com/blog/ict-tools-andenglish-language-teaching/ (data zvernennia: 20.10.2020).

11. Spence P. (2013) Engineering English and the hightech industry: A case study of an English needs analysis of process integration engineers at a semiconductor manufacturing company. English for Specific Purposes. Vol. 32. URL: http://www.sciencedirect.com/ science/article/pii/S088949061200066X. (data zvernennia: 25.09.2020).

12. Varianko T. V. (2012) Navchannia chytannia naukovo-tekhnichnykh tekstiv u nemovnykh vyshchykh navchalnykh zakladakh [Teaching reading scientific and technical texts in non-linguistic higher educational institutions]. Materialy $\mathrm{V}$ mizhnarodnoi naukovo-praktychnoi konferentsii "Suchasni metody vykladannia inozemnoi movy profesiinoho spriamuvannia u vyshchii shkoli" 5-25 kvitnia 2012 r. Natsionalnyi tekhnichnyi universytet Ukrainy "Kyivskyi politekhnichnyi instytut", 15-17 [in Ukrainian].

13. Varianko V., Ivanchenko L. M. (2016) Professionally-oriented foreign language teaching at higher technical educational institutions. Humanitarian Bulletin SU "Pereyaslav-Khmelnitsky Pedagogical University by H. Skovoroda". Supplement 3 to Vol. 36, Volume II (18): Thematic Issue "International Chelpanov's Psycho-Educational Reading”. K.: Gnosis, 261-268. URL: http://chelpanov.eeipsy.org/index.php/eeip/issue/view/9/PDF18 (data zvernennia: 25.08.2020).

Хорочайло О. С. Розвиток професійної компетентності майбутнього фахівця шляхом навчання професійно орієнтованої іноземної мови студентів мовних закладів вищеї освіти

У статті розглядаються нові підходи до навчання іноземних мов за професійним спрямуванням у вищих технічних навчальних закладах. Професійно орієнтоване навчання іноземної мови нині визнано пріоритетним напрямом в оновленні української вищої освіти.

Іншомовне спілкування стає найважливішим компонентом майбутньої професійної діяльності фахівия, тому роль дисиипліни “Іноземна мова" на немовних факультетах і в технічних навчальних закладах значно зростає. Це спонукає педагогів та науковців шукати нові підходи до навчання іноземної мови у професійному напрямі.

Питання підвищення ефективності навчання іноземної мови завжди перебувало в иеетрі уваги викладачів іноземних мов. Особливо гостре ие питання для немовних вишів. С багато проблем, з якими стикаються викладачі іноземних мов таких університетів. Ці проблеми необхідно вирішувати, шукати і реалізовувати в навчальному процесі такі заходи, які сприяли б оптимізачї навчання загалом.

Стрімкий розвиток інформачійних технологій, глобалізаиія міжннародного ринку праиі, конкурениія, щчо зростає, i комерціалізація посилюють суперечності між новими високими вимогами до знань, навичок $і$ вмінь майбутніх фахівиів і їхнім недостатнім рівнем володіння іноземною мовою.

У нашій статті висвітлюється питання зміни підходу до навчання іноземних мов, оскільки за мінімуму навчальних годин у навчальному плані необхідно підготувати фахівия, який добре володіє іноземною мовою. Це можливо через формування у студента необхідних комунікативних здібностей у сферах професійного спілкування в усній та письмовій формі, тобто розвиток комунікативних умінь. Комунікативна мовна компетенція надає людині можливість діяти з використанням специфічних мовних засобів. Тому викладачі іноземних мов шукають нові підходи до активізаиії навчальної діяльності студентів вищих навчальних закладів.

Ключові слова: комунікативна та професійна компетениії, студенти немовного вищого навчального закладу, іншомовна підготовка, методи та підходи. 